\title{
Research Review of Investment Environment of Host Country and China Overseas Direct Investment
}

\author{
Yinglong Yang ${ }^{1, a^{*}}$, Xianmei Fan ${ }^{2, b}$, Yiping Wang ${ }^{3, c}$ \\ ${ }^{1}$ Business School, Hunan Normal University, Changsha, 410081, China \\ ${ }^{2}$ College of Commerce, Chengdu University of Technology, Chengdu, 610059, China \\ ${ }^{3}$ School of Economics, Lanzhou University, Lanzhou, 730100, China \\ aemail, bemail, cemail \\ ${ }^{*}$ Corresponding Author: Yinglong Yang
}

Keywords: Investment environment, Host country, Overseas direct investment

\begin{abstract}
In the process of accelerating China's participation in international investment, the impact of the host country's investment environment on the security and return of China's overseas assets is becoming more and more obvious. When conducting the foreign direct investment, Chinese enterprises should focus on the host country's investment environment. Policy environment, legal environment, cultural environment and financial environment are all the important factors affecting China's foreign direct investment. This paper reviews the relationship between the host country's investment environment and China's foreign direct investment, and provides some references for relevant researchers.
\end{abstract}

\section{Introduction}

As an important force of economic globalization, foreign direct investment has already attracted wide attention of academia, policy circles and industry, and has produced fruitful research results. However, the mainstream research mainly focuses on transnational corporations and host countries. In order to implement the globalization strategy, transnational corporations are eager to expand their foreign investment. Host countries hope to achieve economic and social development goals by introducing foreign capital. The impact of transnational investment on investment countries has not been fully valued. In recent years, with the innovation of the theory of transnational investment and the verification of empirical research, academia and policy circles generally agree that FDI has positive effects on industrial upgrading, foreign trade, employment and other important aspects of the investing countries. Under the condition that economic globalization has become the mainstream of world economic development, transnational operation will become the inevitable choice for Chinese enterprises to survive and develop. Foreign trade and foreign direct investment (FDI) are different forms of choice for transnational operation of enterprises. There is substitution, complementarity and even interaction between the two forms. With the deepening of China's participation in economic globalization and the innovation of its mode, on the one hand, theoretical research has posed new challenges, especially the integration and perfection of the relationship between foreign direct investment and the foreign trade of the developing investing countries from a theoretical perspective, on the other hand, it has also put forward the requirements of empirical research on the practice of foreign investment in various countries. With a view to summarizing the common law. In recent years, China's academic circles have made abundant achievements in implementing the "going global" strategy and developing foreign investment. However, the research on the correlation mechanism between foreign investment and foreign trade, the empirical study on the impact of foreign investment on domestic economy, and the promotion measures of foreign investment in line with international standards are still weak, and there are few high-level research results. This paper will comb the relevant literatures on the relationship between host country's investment environment and 
China's foreign direct investment. This is of great theoretical and practical significance to China's implementation of the "Going out" strategy.

\section{Review of Foreign Literature}

Some foreign scholars have made a comprehensive analysis of the possible factors affecting the location choice of Chinese enterprises'. Ramasamy and Yeung (2010) found that the choice of the host country (region) of Chinese listed companies from 2006 to 2008 depends on the ownership of the listed companies. Large state-owned enterprises are more likely to invest in countries with abundant resource reserves and high political risks, while private enterprises are more likely to focus on the market for investment destinations; while China's outward investment has the goal of seeking technology, it is not seeking core R\&D capabilities, but more inclined to those with commercial capabilities. Technology of value. The study also finds that it is not easy to explain China's state-owned enterprises with the existing FDI theory. Amighini (2011) and others used the data of FDI from 2003 to 2008 by Chinese enterprises in various industries to analyze the influencing factors of FDI location choice. This paper divides the influencing factors of China's FDI into three types: market type, resource type and strategic resource type. The results show that only FDI in manufacturing industry is the type of market acquisition, while resource reserves in host countries are an important factor influencing FDI in resource-related industries, and those countries with abundant natural resource reserves are usually accompanied by a fragile political environment; at the same time, both manufacturing and service industries have the same type of FDI. They are motivated to seek strategic assets and are more likely to invest in developed countries with more advanced technology and management capabilities. Amighini and Rabellotti (2012) also used the 2003-2008 data of China's listed companies to distinguish between state-owned and private ownership of FDI. The results show that private enterprises are more likely to be attracted by the host country's market and technological capital, while state-owned enterprises will invest according to the needs of the national strategy, thus ignoring the host country's political and economic risks to a certain extent.

Some foreign scholars focus on the institutional factors of the host country affecting the location choice of Chinese enterprise's. With the vigorous development of international trade and investment, foreign scholars first noticed the influence of the host country's political risk in the process of FDI. Usher (1965), Root (1968) and others analyzed the impact of nationalization and political instability during the sovereign independence movement of emerging countries on FDI. They first introduced investment risk from the field of commercial risk to the national level. Buckley (2007) used data from 1984 to 2001 on outward FDI flows approved by the governments of 49 host countries for Chinese enterprises to invest in the world. It is found that the host country with higher political risk attracts more Chinese enterprises to make cross-border investment on the contrary, which is totally different from the previous research conclusion based on the foreign direct investment of Western enterprises. The reason may be that the purpose of Chinese enterprise's is not to maximize profits, to be better at dealing with high-risk environment, or to lack the ability to comprehensively assess the risks of the host country. The host country's political risk also makes Chinese enterprises avoid fierce competition because of the western countries 'active evasion, so that they can get lower asset prices. The author also divides the sample into two stages according to the boundaries of 1992, and finds that the location choice of Chinese enterprises' may have different stages. Buckley (2007) empirical analysis of the biggest problem is the use of the Chinese government approved foreign direct investment data, and this data to a certain extent underestimated the actual scale of Chinese enterprises' foreign direct investment, thus affecting the stability and comprehensiveness of the conclusions of the analysis. In addition, the periodic characteristics of China's FDI found in this study also indicate that China's OFDI may present new characteristics from 2001 to the present, so further research is needed.

Other foreign scholars have focused on the differences between developed and developing countries that influence the location distribution of Chinese enterprises'. Cheung and Qian (2009) used data on outward FDI flows of Chinese firms in 31 countries from 1991 to 2005 to find that large 
market size, lower wages relative to China, and abundant natural resource endowments are important attributes that attract Chinese firms to invest directly in the country (but not in China). There is substantial evidence that the main destination of Chinese enterprise's is Africa or some oil-producing countries. This finding proves that seeking overseas markets and natural resources is an important objective of Chinese enterprises', and the impact of relative wage levels on China's OFDI may have different meanings in developing and developed countries. Chinese enterprises can rely on lower levels in developing countries. Relative wage levels provide cheaper labor costs, while investment in developed countries may be mainly for acquiring more strategic assets, such as advanced technology and management knowledge. In addition, Chinese firms will invest more in developing countries that import large quantities from China, possibly because the infrastructure of developing countries is relatively poor and the distribution channels of products are inadequate. A key issue in Cheung and Qian's (2009) study was the use of data on FDI approved by the Chinese government that could be seriously underestimated, thereby affecting the reliability of their conclusions.

\section{Review of Domestic Literature}

Li Quan and Liang Guoyong (2012) empirically examine the impact of political relations on China's foreign direct investment (FDI) on the basis of firm-level and bilateral data, and explain why Chinese enterprises tend to focus on high-political-risk host country investment. Some scholars specialize in studying the political risks of Chinese enterprises' direct investment in the United States. They believe that Chinese enterprises' enthusiasm for direct investment in the United States is often disturbed and restrained by political factors (Zhang Lei, 2014), so the scale of investment in a few developed countries such as the United States is reduced. Hong Junjie et al. (2012) summarized the theory of Chinese enterprises 'foreign direct investment from the perspectives of international business and international economics, believing that institutional factors are the key factors influencing Chinese enterprises' going out.

Some scholars study why China's FDI is concentrated in resource-rich host countries from the perspectives of industry distribution and driving forces of China's FDI (Li Lei and Zheng Zhaoyang, 2012). Some studies began to focus on how the significant growth of foreign direct investment affects the export trade of the home country. If investment in a host country can increase the technological content of its trade products, it will increase the scale of investment in the host country (Zhang Haibo, 2014; Qi Chunling and Zou Chao (2013) studied the impact of the institutional quality of the host country on the location choice of China's FDI. It is found that the higher the quality of the host country's economic system and the rule of law system has a significant positive impact on China's foreign investment, and the better the quality of the host country's formal system is, the more it will attract China's investment. Some domestic scholars have also discussed the main determinants of location choice of China's foreign direct investment. Based on the static panel model, Li Hui (2007) used the panel data of 55 host countries and regions from 1980 to 2004 to test the various influencing factors of China's FDI. It is found that the per capita GDP, export quantity, industrial structure, total world trade and total world demand of the home country have a significant impact on its OFDI specification. Li Meng and Yu Jinping (2011) used the panel data of China and 74 investment host countries and examined the correlation between the location advantages of each investment host country and China's foreign direct investment. It is found that the resource endowment and market size of the host country have an important impact on the size of China's FDI. Xiang Benwu (2005) used the fixed effect panel model to test the determinants of China's foreign direct investment (FDI). However, due to the availability of data, the sample is small and the conclusion is not reliable. Xiang Benwu (2009) further uses the panel data of China's FDI to 50 countries or regions from 2000 to 2007 to reveal the dynamic effect of China's FDI by using GMM estimation method. Through empirical study, we find that the host country's market size has a significant negative impact on China's investment in the host country, while bilateral trade links and exchange rates have a significant positive impact, while the host country's relative wage level has no significant impact on China's OFDI. From the dynamic point of view, the pre-investment has no significant impact on the current 
investment, indicating that the present stage of China's cross-border investment is still lack of continuity.

Some scholars also analyze one or several factors that influence China's foreign direct investment. The resource seeking phenomenon of China's foreign direct investment, which has been heated by some foreign media recently, is discussed. Li Lei and Zheng Zhaoyang (2012) based on the 2003-2008 China's FDI sub-national panel data, using GMM analysis method, China's OFDI resource-seeking research. The results show that China's OFDI has strong resource-seeking characteristics and is more obvious in developing countries in the Americas and Asia, but not in developed countries and Africa. In addition, China's thirst for minerals is greater than its thirst for oil. The resource seeking phenomenon of OFDI in China may be caused by the energy consumption in China and the pricing strategy of petroleum minerals in the world. Dukai and Zhou Qin (2010) used bilateral data from 1995 to 2006 to examine China's foreign direct investment (FDI). The study concludes that OFDI in China is a kind of investment behavior of enterprises trying to cross trade barriers, which has obvious "induced" characteristics. Trade barriers represented by anti-dumping and tariffs play an important role in promoting Chinese enterprises' foreign direct investment and location selection. The study also finds that there are country (regional) differences in this feature, and an important reason for this difference is the size of the bilateral market constraints. Wei Junliang and Chen Ligao (2009) investigated the non-financial FDI of Chinese enterprises in 73 host countries from 2003 to 2006. The research shows that the political risk of each host country has a significant negative impact on China's non-financial FDI.

\section{Conclusion}

Most studies believe that the host country's economic risks have an impact on the inflow of foreign investment, but there is no consensus on the extent, direction and specific ways of the impact. From the perspective of the home country, this paper mainly discusses whether the economic and financial risks in the world affect the total amount of China's foreign investment. To discuss whether the level of economic and financial risks of the host countries affect the scale of China's investment, we must start from the perspective of the host country.

\section{Acknowledgement}

This research is the result of Hunan Province College Students Research Learning and Innovative Experiment Project (201810542009).

\section{References}

[1] Yang Yaping, Li Tengteng. Business Environment and Outward FDI Location Selection of Chinese Enterprises [J]. Industrial Economic Review, 2018(3): 129-147.

[2] Cheng Zhonghai, Nan Nan. The Host Country Institutional Environment and Chinese Outward Foreign Direct Investment Potential under the Background of The Belt and Road [J]. Soft Science, 2018, 32(1): 36-40.

[3] Zhao Beiwen. Chinese Enterprises'Choice of OFDI's Location under the Circumstances of Economic Globalization [J]. World Economy Studies, 2015(6): 119-126.

[4] Zhou Jing, Zhang Limin, Ge Yao. Impact of Institutional Environment on China's OFDI: A Study from Perspective of Heckman Two Stage Model Analysis [J]. International Business, 2015(1): 104-113. 